\title{
Assessing Domestic and Regional Factors Influencing Ghana's Export Trade in Africa
}

\author{
Louis Kofi Desire Atimu, Wenping Luo \\ School of Economics and Management, Shanghai Maritime University, Shanghai, China \\ Email: louisatimu116@yahoo.com,wluo@shmtu.edu.cn
}

How to cite this paper: Atimu, L. K. D., \& Luo, W. P. (2021). Assessing Domestic and Regional Factors Influencing Ghana's Export Trade in Africa. Open Journal of Business and Management, 9, 103-113. https://doi.org/10.4236/ojbm.2021.91006

Received: November 20, 2020

Accepted: December 21, 2020

Published: December 24, 2020

Copyright $\odot 2021$ by author(s) and Scientific Research Publishing Inc. This work is licensed under the Creative Commons Attribution International License (CC BY 4.0).

http://creativecommons.org/licenses/by/4.0/

\begin{abstract}
Ghana's hopes of increasing export trade volumes and destinations to domestic economies within the African continent in order to foster growth and climb the economic ladder to become a middle income country is very much achievable. However, this objective to a great extent depends on regional integration and cooperation rather than the efforts of one single country or economy. Intermediary influencers such as distance play a major role in determining export destinations for Ghana, whilst endogenous issues like customs procedures and border related issues, tariffs and import quotas, and trade restrictions within the importing countries heavily affect Ghana's trade volumes and destinations within the region. Thus the establishment of robust economic bodies and platforms to institutionalize universal trade regulations and reforms to enhance effective trade among member countries and reduce trade transactional processes, lengthy customs procedures and trade restrictions will not only affect Ghana positively but all other domestic economies within the region. Enjoying an effective export trade will also come as a result of the continent investing heavily in infrastructural development, complemented with effective transportation systems, better service provision via advanced technologies and human capital development.
\end{abstract}

\section{Keywords}

Ghana, Africa, Export Trade, Economic Growth, Regional Integration, Infrastructural Development

\section{Introduction}

Ghana seeks to increase its export destinations to many countries within Africa and beyond and thus it is very imperative to assess the various ways by which the country can realize this ambition by looking at the trend of Ghana's export des- 
tinations and its trade performance within and outside of the continent and the very factors that influence its performance. Ghana has mainly targeted the Southern part of Africa with South Africa being its main destination; whereas export trade with other developing and less developed countries within the African borders has been significantly low. In terms of foreign markets, the country has mainly benefited from its trade relations with Asian countries such as China, India and the United Arab Emirates whilst it has also profited from the African Growth and Opportunity Act (AGOA) which allows for more than six thousand products to enter the market of the United States of America duty and quota free from member countries (Tralac, 2020). According to the World Trade Organization (WTO, 2008), Ghana's export to the United States of America had increased by a significant $14.7 \%$ although the latest trends seem to show that exports to developed countries have shifted to developing countries which has led to reduction in the total number of exports to developed countries. This scenario is evident with China, India and the United Arab Emirates assuming a combined 36.4\% of Ghana's export volumes in 2019 (Trading Economics, 2020).

Increasing export volumes and export destinations are also part of Ghana's ambition of becoming a middle income country in a bid to improve its economy and decrease poverty, and this was responsible for the inauguration of Ghana's trade policy document in 2004 (WTO, 2014). The nation's main intent for the development of such policy was so that the country will become a major agro-industrial economy. Furthermore, a Poverty Reduction Strategy Policy was adapted by the government of Ghana to aid in the realization of this national objective, with a bid to inflate export systems and quantity as well as increasing the number of destination countries for its exports. The Ghana Trade Support Programme structured in 2005 was a follow up of the Trade Policy document, having been approved by the cabinet of Ghana. The enactment of all these trade documents was to propel the nation towards expansion in total exports and exports destination. A broad understanding explains Ghana's intention to improve intra-regional and global integration, enhance export base diversity and strength to reach many African countries and foster agricultural processing and other developing and developed economies. According to Amoah (2014), total trade between Ghana and other domestic countries within the African borders on average increased from $0.90 \%$ in 1980 to $3.13 \%$ in 2007 which was a good indicator considering the fact that that of the whole continent with external economies only averaged $1.89 \%$ within the same period. Whilst exports from Ghana to other domestic economies within the African borders advanced from $2.46 \%$ to $25.51 \%$ within the same period (1980-2007), its imports from other countries within the continent increased to $12.11 \%$. One major institution whose association is helping to boost Ghana's ambition towards achieving a robust intra-regional trade is the Economic Community of West African States (ECOWAS). Member states within this organization have sought to encourage trade liberalization and foster custom union since 1990; however, the conformance of the trade regimes which 
incorporated an advocacy for external transportation cost has been hampered. In general, Ghana's export trade to developing countries within Africa has been stationary compared to its export trade with other developing economies beyond the domestic continent. This can be attributed to the underperformance of ECOWAS in promoting effective regional integration, with further extension to other countries within the whole continent. Thus, an improvement of the overall economic integration of African economies will help Ghana expand its export destinations, boost Gross National Product and overall be able to secure the objective of attaining a middle income status.

\section{Literature Review}

\subsection{The Nature of Ghana's Exports}

Ghana's total exports have mainly been dominated by primary products and commodities which are labor intensive whilst not much is exported from manufactures. Ghana's economy is sustained by the agricultural sector which just like most Sub-Saharan African countries contributes much to the GPD growth of these nations. Ghana's export composition has mainly been dominated by Gold and Cocoa. Production volumes of these two major export commodities from Ghana are volatile as well as their prices which are subjected to price fluctuations on the international market. Cocoa is the predominant cash crop agro product of the country and its contribution to the nation through foreign exchange has been immense. Although Ghana accrues foreign exchange from some other cash crops like coconut, palm oil and cotton, the larger percentage is still held by cocoa (Amoah, 2014). The agricultural sector's immense contribution to the GDP growth of the nation is largely due to the production of cocoa. The government of Ghana through the provision of extensive services and subsidized seeds has supported the agricultural sector, although in order to encourage domestic processing, it has implemented policies to reduce the exportation of timber whilst regulations on the ban of the export of commodities such as bamboo and unprocessed logs have been put in place. Apart from cocoa and other cash crop products, gold assumes the nation's second largest export commodity with a share of over 30\% of the total exports (International Trade Administration, 2020).

Figure 1 shows the trend of Ghana's cocoa production and exports between $2012 / 2013$ and $2019 / 2020$. The data shows the $2016 / 2017$ period as grossing the highest cocoa production and export with 778,000 tonnes whilst 2014/2015 recorded the lowest with 740,000 tonnes.

Figure 2 shows the production of gold in Ghana from 2012 to 2019. The data shows that although Ghana's gold production was very low in 2012 with a volume of $86,972 \mathrm{~kg}$, gold production peaked in 2014 at $137,090 \mathrm{~kg}$ which is still the highest recorded volume for the country.

Although the nation has a vast industrial sector, manufacturing activities have mainly revolved around the processing of agricultural products with steady advances in textile, electronics and pharmaceutical productions. In order to protect 
this domestic manufactures and their parent industries within the country, tariffs for imports on related products from external countries have been significantly increased by some governments and thus reducing international competitiveness and promoting domestic dominance (International Trade Administration, 2020; Amoah, 2014; Mutume, 2006).

Ghana's export to Asia has seen a steady increase with its trade relations with China being a fundamental factor. More so, the country exports to other countries in Asia like India and the United Arab Emirates; these three nations registered as the first, third and fifth major export destinations for Ghana in 2019. Other European countries like Switzerland, Netherlands, France and Italy are part of Ghana's favorite destinations with other global economies such as the United Kingdom and South Africa (Trading Economics, 2020).

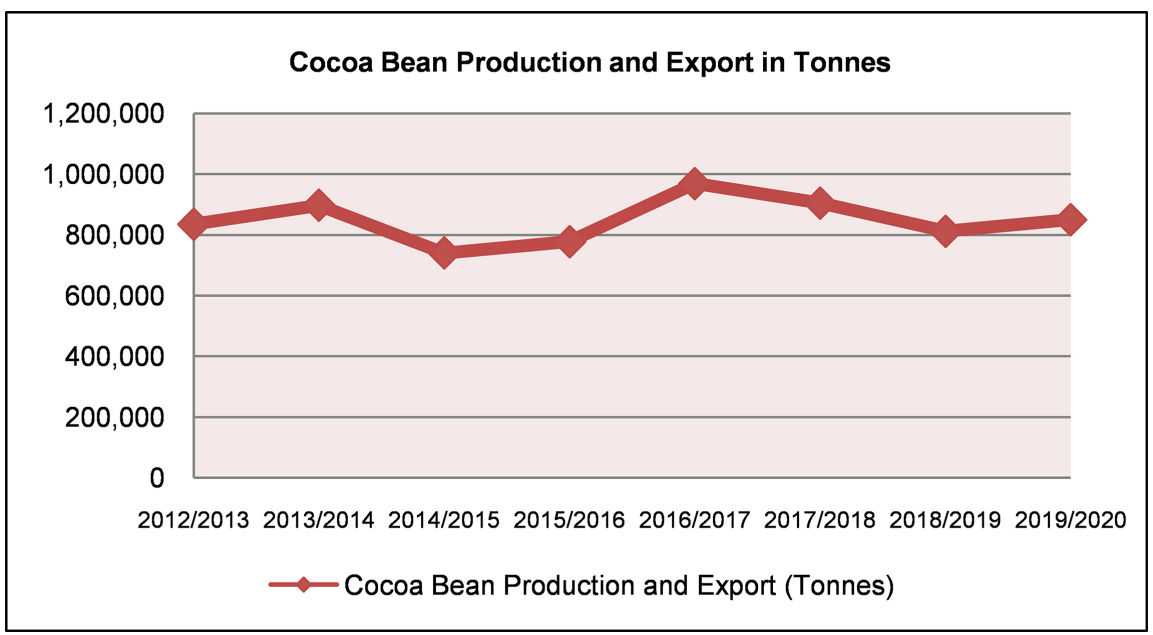

Figure 1. Ghana's Cocoa Production and Export between the periods (2012/2013 and 2019/2020). Data Source: Trading Economics, 2020.

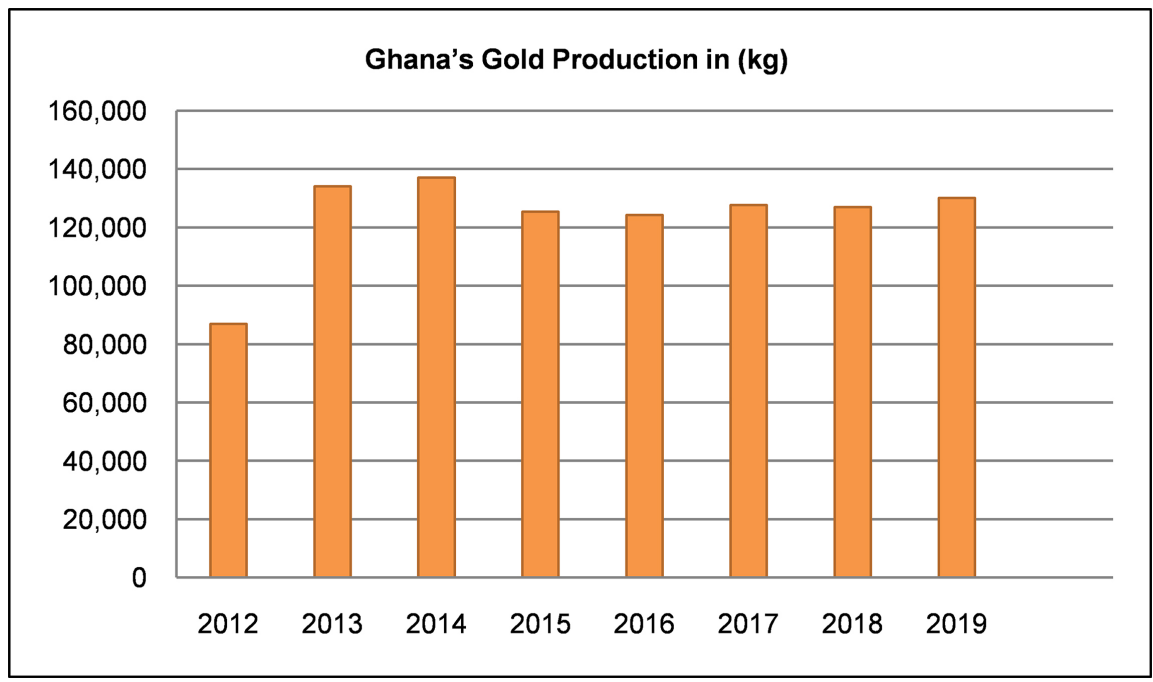

Figure 2. Ghana's Gold Production between the periods of 2012 and 2019. Source: Ceicdata, 2020 . 
Table 1 shows Ghana's export destination has mainly been the continent of Asia with major destinations in countries such as China (17\%), India (14\%) and United Arab Emirates (5.4\%). These three countries commanded a combined $36.4 \%$ of the total exports of Ghana, with other countries in Asia receiving smaller exports percentages.

Ghana's export destinations within the continent of Africa have mainly been South Africa. The country shares borders with Burkina Faso, Cote d'Iviore and Togo and these nations form part of the top three favorite regional export destinations for the country as is evidenced in export values in 2019.

Figure 3 shows ten of Ghana's major export destinations for 2019 with South Africa amassing the greatest with an import value of $\$ 1.97$ billion dollars. Burkina Faso, Nigeria, Togo, Senegal, Sierra Leone, Ivory Coast, Mali, Niger and Benin grossed \$277.69 million \$164.06 million \$159.95 million, $\$ 82.62$ million, $\$ 60.1$ million, $\$ 52.7$ million, $\$ 44.3$ million, $\$ 43.4$ million and $\$ 41.4$ million dollars respectively in imports from Ghana.

Table 1. Ten of Ghana's major export destinations (globally) for the year 2019.

\begin{tabular}{cccc}
\hline Country & Year & Export Value $(\$)$ & Percentage $(\%)$ \\
China & 2019 & $\$ 2.81 \mathrm{~B}$ & $17 \%$ \\
Switzerland & 2019 & $\$ 2.47 \mathrm{~B}$ & $15 \%$ \\
India & 2019 & $\$ 2.38 \mathrm{~B}$ & $14 \%$ \\
South Africa & 2019 & $\$ 1.97 \mathrm{~B}$ & $12 \%$ \\
Netherlands & 2019 & $\$ 966.31 \mathrm{M}$ & $5.8 \%$ \\
United Arab Emirate & 2019 & $\$ 899.16 \mathrm{M}$ & $5.4 \%$ \\
United States & 2019 & $\$ 704.28 \mathrm{M}$ & $4.2 \%$ \\
United Kingdom & 2019 & $\$ 415.12 \mathrm{M}$ & $2.5 \%$ \\
France & 2019 & $\$ 377.03 \mathrm{M}$ & $2.2 \%$ \\
Italy & 2019 & $\$ 308.10 \mathrm{M}$ & $1.8 \%$ \\
\hline
\end{tabular}

Data source: Trading Economics, 2020.

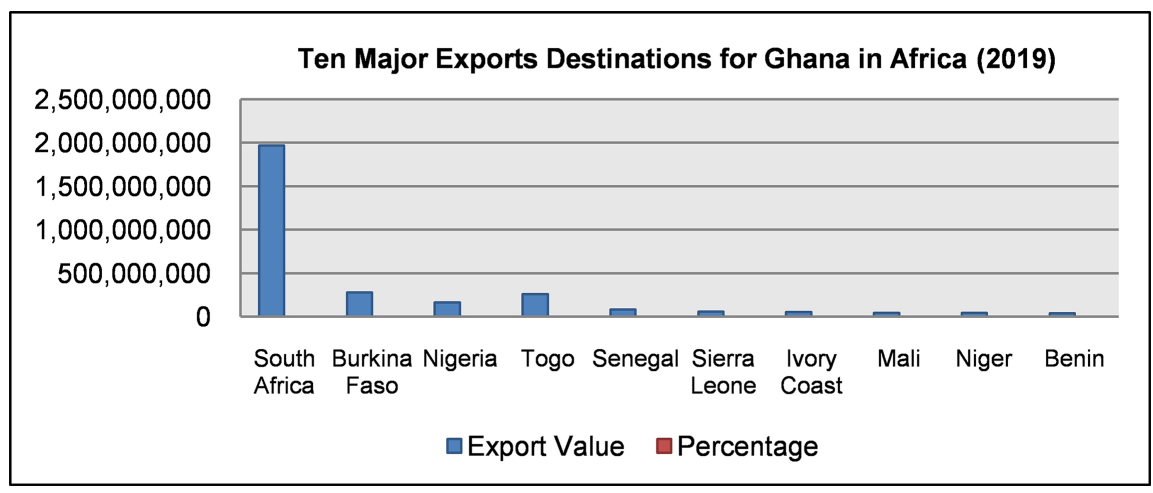

Figure 3. Ghana's major exports destinations in 2019. Data Source: Trading Economics, 2020. 


\subsection{Factors Affecting Ghana's Export Trade with Other African Countries}

The introduction of maritime transport has led to the drastic reduction of transport cost in recent decades which according to Baldwin and Martin (1999) has promoted an average two thirds (2/3) reduction of real port charges and ocean freight per short ton. The trade performance of many countries within the region of Sub-Saharan Africa has seen significant improvement although as compared to other foreign countries still lags behind, which is arguably due to the issue of limited technological advancements, transport cost and ineffective regional integration systems (Amoah, 2014). A review conducted by World Bank (2009) exposed what had been asserted some researchers on the issue of high transport cost to transport service companies being the obstacle to trade performance in Africa. Contrary to these assertions, the World Bank explained that the general cost of transport services is not excessively high but rather overall trade cost within the continent is very high and that has resulted in the trade limitations for the continent. Traced to the research of Amjadi and Yeats (1995), it explained that intra-regional nominal freight rates on exports in Sub-Saharan Africa are relatively higher than export cost between the continent and other external countries and regions outside the borders of the African continent. It was concluded in their work that the overall trade cost was more of an obstacle to the trade development in the continent than the partially asserted reason of high import tariffs and trade restrictions.

Trade cost is the overall cost involved in getting a commodity from the producer to the customer; that includes product production cost, transportation and other value-added service costs. Trade cost between producers and customers within Ghana will escape additional costs such as tariffs and other port charges but these factors are very critical to determining exports to external countries. Tariffs are not the same in every country and vary by country specifics and domestic regulations in the importing countries and thus depending on the geographical location of a country by region or continent, transport costs could range from $8 \%$ and $13 \%$ (Marquez-Ramos, 2007). There has been a general effort by world economies to encourage globalization and strengthen regionalization to bring about certain policies to aid in tariff barrier reductions. However, some countries in Africa have either restored some trade restrictions which were before removed whilst others have built upon old restrictions and this affects the level of Ghana's export trade with such countries. An instance is that of Nigeria which dealt away with quotas and licensing but significantly escalated the number of import bans, furthermore, although Cote d'Iviore cut down quota rates, it appreciably increased its tariffs (Amoah, 2014). A general analysis of high import tariffs on certain foreign products indicates low exports volumes for that particular product. This is because since tariffs are part of the calculation of the total cost of trade and foreign product prices for that matter, it means that the prices of such goods will be relatively high. Thus high tariffs increases costs and 
therefore reduce trade. However, high foreign tariffs on specific commodities are mainly to ward off and limit external or foreign competitors from competing with domestic firms in the production of similar products.

The issues of tariffs and transport costs have not been the only obstacles in trade for Ghana to countries within the Sub-Sahara African region and the continent as whole, other issues such as infrastructural development have been another upsetting scenario not only for the country but other nations in terms of trade effectiveness and efficiency. Sub-Saharan Africa has been plagued with the problem of poor infrastructural development and incapacitated institutions. In general, the nature of roads, highways and transportation (shipping) equipments lags behind as compared to foreign counterparts. Although national leaders within the continent established certain initiatives such as the intra-African trade and other projects in order to establish a strong economic integration among nations, the initiative has enjoyed little success as the poor nature of nature of road infrastructures and transport services have hampered the realization of this objective. However, regional and continental ambitions of such magnitudes demand on the corporation of all members and the long term financial commitments by domestic governments to make it happen. Most countries within the continent only invest as little into the development and maintenance of their transport sector and infrastructure. Estimation by Limão and Vernables (2001) showed that the average landlocked countries in Africa experience a 46\% higher transportation cost than the other economies which are not landlocked. Their research also explained that poor roads and infrastructure accounted for $40 \%$ of the total transportation cost for coastal economies whilst a significant $60 \%$ of the total transportation cost for landlocked economies is attributed to the same factor. The issue of poor roads and transport systems is very critical to reducing the cost charges for most especially road transportation and overall trade cost. This is because although there could be average freight rate charges for related or similar cargo across countries all over the world with only a slight difference, most cargoes or commodities begin with inland transportation and thus influences the overall transportation cost. Transporting cargo to and from landlocked countries implies that cargoes will have to be offloaded onto trucks and transported on land to either reach the ports or their destinations which incurs higher costs. All things being, if a country's road transport systems are bad or the specific route to be used by the truck driver is poor, it means that transport cost will eventually be higher than expected. More so, distance between the landlocked country and the coastal country will significantly influence the transport cost, thus the farther a country or destination is from the coastal country, the more expensive the transportation cost will be and the higher the total trade cost. There have been many projected benefits for the African economy through investment and sustenance of highway networks in Trans-Africa, and one of such projections was made by Buys, Deichmann, \& Wheeler (2006) who forecasted an anticipated increase of $\$ 10$ billion to $\$ 30$ billion annually in returns on 
investments on road and infrastructural development within the continent. Some researchers have argued that institutional organizations and their affiliated deficiencies such as corruption and weak policies together with bureaucracy and competition in market institutions are some of the factors affecting the development of transportation systems (Collier et al., 2003; North, 1990). In addition to this, other researchers have also attributed the issues hampering trade among countries in Africa to political factors such as ethnic fragmentation, conflicts and poor governance (Gyimah-Brempong et al., 1999) whilst others have asserted that low public investments into developing the transport sector by providing both human and physical capital with further investments in technology are the reasons for high trade cost within the continent (Krugman, 1990; Ancharaz, Mbekeani, and Brixiova, 2011). Other authors (Mbabazi et al., 2003) argued that in considering the overall factors responsible for the high trade cost within the continent, segregated resource endowments, geography and other natural barriers should be included to infrastructural constraints. Evidences from the work of Morrissey (2009) which reviewed the influence of logistics and transport cost on the overall trade cost in Africa revealed that the average transportation cost within the borders of the continent is higher compared to that of other foreign regions and this has become an impediment for trade and growth in Sub-Saharan Africa and the continent as a whole. According to a research done by Edward (2008), the impeding factor to export supply response in Africa can be traced to poor infrastructures, weak institutions and defective regulatory frameworks. To add up to these assertions, (Djankov et al., 2006) explained that in general, domestic transport costs and extensive delays are responsible for hampering trade efficiency within the continent whereas Collier and Vernables (2000) showed in their works that expensive transaction cost together with poor infrastructural development and climate changes have not favored most manufacturers and exporters domestically. Thus the general argument that the works of these researchers point to is the fact that the impeding factors which have hindered the growth of trade in Africa are poor institutional and infrastructural development as well as frail response volumes. Therefore advancement in trade for Ghana and Africa for that matter demands that policy reforms and adequate investments be made into most especially the transport sector by governments and public institutions to improve infrastructure and offer better services in order to lower overall trade cost. Furthermore, investments in transportation and logistics efficiency services especially with sea and road transport are very critical in achieving the overall cost reduction objective. Investments in advanced technology and human capital development through education and training to make use of such technologies' operational and administrative procedures will facilitate quick transportation, reduce lead times and cut down undue delays in domestic transportations which will help reduce trade cost in the continent (Morrissey, 2009). If domestic roads are giving the due attention and the needed public investment needed in developing infrastructure, establishing the right institutions and pro- 
viding adequate services, exports and for that matter trade will significantly be boosted as total trade cost will be reduced as new market opportunities are accessed with ease. More so, transportation ease will influence high export volumes for exporting countries which will then increasing foreign exchange and enhancing economic growth.

There are also border related issues with their own complexities in many countries within the whole continent which affects Ghana's trade with other countries in African. Many disadvantages are attached to procedural inefficiencies on borders to local governments and customer businesses. Procedural irregularities can hinder business transaction speed and efficiencies with ripple effects such as longer and unpredictable lead times which could even cause loss of business opportunities and the damage of perishable goods. Most countries like Ghana rely on the services of the customs division or administration to implement policies and regulations to oversee the administration of port operations in conformity with national laws and also to make sure illegal, prohibited or contaminated goods are not allowed transportation between national borders. According to World Bank (2009); Purfield, Farole, and Im (2014), the region of Sub-Saharan Africa registers more imports and exports procedures such as customs declaration and clearance than any other region. This phenomenon shows that most countries in the region including Ghana lags behind foreign countries in terms of trade transactional processes and this negatively affects trade. Thus greater regional integration to foster trade could help eliminate the many challenges faced in the region.

Other factors affecting trade and transport efficiency is political instability. Although much research has not been done concerning the effect of political instability on export trade, a study conducted by Srivastava and Green (1986) analysed the results of data from 45 export countries whilst assessing 82 importing countries which showed that the level of exports for stable nations in bilateral trade is much higher than other nations experiencing political unrest. Political instability within a country is more likely to affect local businesses and most especially businesses who either import their products or services from other countries. Hence the ripple effect of a stable economy is that overall trade within and outside of such countries will be steady and have the capacity to expand and increase.

In addition to this, factors like distance also affect Ghana's domestic exports within the continent. This is because, all things being equal, a longer transportation distance is more likely to generate a higher transportation cost. Ghana is involved in export trade with all three countries along its boarders (Nigeria, Togo and Burkina Faso), and this could be attributed to the fact that it is much easier to trade with nearby economies than others that are very far. Product prices having longer distances between the exporting and importing countries will eventually have higher prices since transportation cost is very much included in the overall prices of commodities. This together with import duties 
and tariffs will eventually make product prices shoot up on arrival at the importing customer's final location or destination. The likelihood effect of such export is that there will be average quantities demanded.

\section{Conclusion}

Ghana's ambition to realize its trade objectives in terms of export volumes and destinations within the continent depends on the holistic investment and development of Africa's trade and transport systems. This is because undertaking a cross-border developmental project cannot be done by one country but rather all stakeholders. Thus countries within the continent should contribute finances, resources, human expertise and technological assets to fund the development of the transport sector and its infrastructures. A long term development plan which will secure the full commitment of the various domestic governments and all stakeholder economies should be adopted with a greater on long term infrastructural building and better service provision. More so, the effective operations of regional bodies and institutions as well as reformation of trade processes and regulations amongst domestic economies should be given a major priority, whereas some measures should be put in place to reduce trade restrictions and high import tariffs in order to foster a much effective and a less restrictive trade flow between domestic economies.

\section{Conflicts of Interest}

The authors declare no conflicts of interest regarding the publication of this paper.

\section{References}

Amjadi, A., \& Yeats, A. J. (1995). Have Transport Costs Contributed to the Relative Decline of Sub-Sahara Africa Exports? Some Preliminary Empirical Evidence. Working Papers in International Economics, No. 1559, Washington DC: World Bank.

Amoah, G. O. (2014). Intra-African Trade: Issues Involved in Improving Ghana's Trade with the Rest of Africa.

Ancharaz, V., Mbekeani, K., \& Brixiova, Z. (2011). Africa Economic Brief; Impediments to Regional Trade Integration in Africa.

Baldwin, R. E., \& Martin, P. (1999). Two Waves of Globalization: Superficial Similarities, Fundamental Differences. https://doi.org/10.3386/w6904

Buys, P., Deichmann, U., \& Wheeler, D. (2006). Road Network Upgrading and Overland Trade Expansion in Sub-Saharan Africa. Policy Research Working Paper Series 4097, Washington DC: The World Bank. https://doi.org/10.1596/1813-9450-4097

Ceicdata (2020). Ghana Gold Production.

Collier et al. (2003). Breaking the Conflict Trap: Civil War and Development Policy. https://doi.org/10.1037/e504012013-001

Collier, P., \& Vernables, A. J. (2000). Urban Infrastructure for Development.

Djankov, S., Freund, C., \& Pham, C. (2006). Trading on Time. World Bank Policy Research Working Paper 3909, Washington DC: World Bank. 
https://doi.org/10.1596/1813-9450-3909

Edward, L. (2008). Trade Related Business Climate and Manufacturing Export Performance in Africa: A Firm-Level Analysis.

Gyimah-Brempong, K. et al. (1999). Corruption, Growth, and Income Distribution: Are There Regional Differences?

International Trade Administration (2020). Ghana-Commercial Guide; Trade Barriers.

Krugman, P. (1990). Increasing Returns and Economic Geography. https://doi.org/10.3386/w3275

Limão, N., \& Venables, A. J. (2001). Infrastructure, Geographical Disadvantage, Transport Costs and Trade. World Bank Economic Review, 15, 451-479. https://doi.org/10.1093/wber/15.3.451

Marquez-Ramos, L. (2007). Understanding the Determinants of International Trade in African Countries. An Empirical Analysis for Ghana and South Africa. Castellon: Universitat Jaume I and Instituto de Economia Internacional.

Mbabazi, J., Milner, C., \& Morrissey, O. (2003). The Fragility of Empirical Links between Inequality, Trade Liberalisation, Growth and Poverty. In R. van der Hoeven, \& A. Shorrocks (Eds.), Perspectives on Growth and Poverty, Tokyo and New York: United Nations University Press.

Morrissey, O. (2009). Transport and Trade Costs in Africa. Nottingham: University of Nottingham, School of Economics.

Mutume, G. (2006). New Barriers Hinder African Trade; Health Standards in Rich Countries Limit Continent's Ability to Export.

North, D. C. (1990). Institutions, Institutional Change and Economic Performance. Cambridge: Cambridge University Press. https://doi.org/10.1017/CBO9780511808678

Purfield, C. M., Farole, T., \& Im, F. (2014). South Africa Economic Update: Focus on EXport Competitiveness. Washington DC: World Bank, South Africa Economic Update No. 5.

Srivastava, R., \& Green, R. (1986). The Determinants of Bilateral Trade Flows. The Journal of Business, 59, 623-640. https://doi.org/10.1086/296358

Trading Economics (2020). Ghana Exports by Country in U.S. Dollars, According to the United Nations COMTRADE Database on International Trade.

Tralac (2020). African Growth and Opportunity Act (AGOA).

World Bank (2009). Geography in Motion: Density, Distance, and Division in Sub-Saharan Africa. In Reshaping Economic Geography: World Development Report 2009 (pp. 283-285). Washington DC: World Bank. https://doi.org/10.1596/9780821376072_G4

WTO World Trade Organisation (2008). Trade Policy Review. Ghana.

WTO World Trade Organisation (2014). Trade Policy Review. Ghana. 